\title{
Evaluating Country Food in the Northern Native Economy
}

\author{
PETER J. USHER ${ }^{1}$
}

\begin{abstract}
A means is sought of estimating the value of domestically-produced country food, which is of considerable importance in the northern native economy. The problems involved include the determination of the actual volume of production as well as the uses made of it, the evaluation of income in kind, particularly through the imputation of cash values, and the assessment of the intangibles involved in any direct comparison between the modern and traditional sectors of the northern economy. It is concluded that substitution costs provide the most appropriate measure of value and their use is, therefore, recommended, but with the caution that they cannot serve to measure the value of the activity or environment which produces the country food.
\end{abstract}

RESUMÉ. De l'évaluation de la nourriture autochtone dans l'économie des indigènes du nord. On cherche un moyen d'estimer la valeur de la nourriture autochtone produite localement et qui est d'une importance considérable dans l'économie des peuplades indigènes du nord. Les problèmes que présente cette estimation comprennent la détermination du volume réel de la production aussi bien que les usages qui en sont faits, l'évaluation du revenu en espèces, en particulier au moyen de l'imputation de leur valeur au comptant, et la cote des intangibles que présentent les comparaisons entre les secteurs modernes et traditionnels de l'économie septentrionale. On conclut que les coûts de substitution présentent la mesure de valeur la plus appropriée et leur usage est, par conséquent, recommandé avec toutefois la réserve qu'ils ne peuvent pas servir à mesurer la valeur de l'activité ou de l'environnement qui produit la nourriture autochtone.

РЕЗЮМЕ. Оченка продуктов питания, добываемъх и произодимых коренны.и населением северных районов. Ищутся способы определения стоимости продуктов, добываемых или производимых коренным населением в условиях домашнего хозяиства и имеющих в северных ранонах важное вначение для местной вкономики. Рассмстриваемые проблемы включағот: определение фактического объема домапнего производства, а также формы использования полученньт продуктов; оденку доходов от домашнего ховниства посредетвом введения денежных эквивалентов отдельных продуктов; попытку сопоставления традиционного и современного секторов экономпки Севера. Делается вывод о том, что денежный эквивалент наиболсс полно характеривует ценность продуктов, однако, наряду с рекомендагией о примененни денежных әквивалентов, подчеркивается и то, что ими не следует оценивать ни человеческую деятельность, ни качество окружающей среды, в которой добываются продукты питания.

\section{INTRODUCTION}

The economy of the Canadian North has for many years been noteworthy for its duality: it has two coexistent sectors - one modern and industrial, and the other traditional and domestic. The view is widely held in southern Canada that the traditional sector is rapidly and inevitably declining in favour of the modern one and, indeed, that the change will in the long run benefit the North. There is growing evidence, however, that those engaged in traditional activities do not

\footnotetext{
1Socio-economic consultant, P. O. Box 2000, Inuvik, N.W.T., Canada.
} 
share this view, and hunting and trapping especially remain of vital, though altered, significance to native people who are in the majority in most parts of the North. Further, the earlier situation in which the two sectors of the economy had little influence on each other is giving way to one in which they are increasingly in conflict. In particular, the exploration for extraction and transportation of oil and gas is considered by native northerners to pose a serious threat to the future of hunting and trapping (Usher 1972a, 1975a).

It is generally thought important in modern industrial society to attach numerical values to human activities. This is particularly true of economic activity, and economists have, over the years, developed sophisticated means of measuring volume and value of production and exchange. Such means are, however, generally based on the assumption that production and exchange occur in the context of a market economy and the availability of cash. Economists have not yet devised adequate methods of evaluating these functions where there is no market system or no cash. In measuring economic activity in the North, they have generally failed to comprehend the duality which exists there; they either ignore the problem by omitting those elements of northern domestic production which do not enter the market place, or else assign cash equivalents on the assumption that the functions of the traditional sector can be integrated with those of the modern. Both approaches involve bias in that the modern sector is regarded as the norm, and in both there is invariably an undervaluation of the activity of the traditional sector. Given the increasing conflict between the two sectors, this situation is in need of correction. A re-examination of the problem of measurement is therefore of both theoretical and political significance.

The purpose of the present paper is to discuss the possibilities of imputing cash values to country produce, and to study some of the elements which must be considered in doing so; also to suggest some refinements to the methods for the measurement of the value of traditional economic activity that are now in use and to comment on the limitations of such improvement in the overall problem of evaluation and comparison.

The general problem of measurement may be seen to fall into three parts: first the determination of the actual volume of production and its disposition and use; second, the evaluation of income in kind, specifically imputing a cash value to country food which is consumed domestically; and third, the examination of the intangibles involved in any direct comparison of the modern and traditional sectors of the economy, and the limits which these place on the utility of imputing a value to income in kind. These remarks refer particularly to the problem as it exists in the Northwest Territories of Canada, although they should be broadly applicable to other parts of the North, and indeed any area where people live by hunting and fishing.

\section{VOLUME OF PRODUCTION}

Harvest, in terms of game management, means the total number of animals removed from a population by hunting or trapping activity. Only rarely have such figures been compiled, and then they have usually been the result of isolated 
observations made for a year or two in any one locality. Harvest, in terms of human benefit, means the total number of animals retrieved by hunters and trappers and which are potentially useful to them. The difference between these two figures is the loss incurred in certain forms of harvesting, such as fur bearers being destroyed in traps by other carnivores before removal, seals sinking after being shot, and fish destroyed in nets by other aquatic fauna before lifting. Only rarely have figures of such losses been compiled, and then are based on only occasional observations. It is, therefore, necessary to use data sources which record approximate harvest levels, and to estimate their reliability and the degree of approximation involved.

There exists a variety of records based on government and private data which have approximated, or continue to approximate, harvest levels. The purpose, nature and reliability of these data series have been extensively discussed in a previous report (Usher 1975b); they almost invariably underestimate native resource use, the degree of underestimation varying from very slight in the case of fur bearers (which enter the cash economy and can be evaluated directly) to moderate in the case of most big game animals, and to very large in the case of seals and migratory birds. In addition, there are no regular records kept at all of the take of certain species, such as fish, most small game, some birds, and most marine mammals.

Any assessment of the value of country produce which relies solely and uncritically on official sources (e.g., the Fur Export Tax Returns, the General Hunting Licence Returns, and the Traders Fur Record Books, all maintained by the government of the Northwest Territories) begins by underestimating the true volume of domestic production by anything from five to fifty per cent, and perhaps more. Furthermore, occasional statistics, such as are found in government reports and independent research studies, and relate to single or sporadic occasions only, must be treated with extreme caution. Short term, cyclic-like variations, as well as long term shifts in the availability of many boreal and arctic species, are well known. General inferences from occasional statistics are therefore extremely risky.

Even when the harvest is known, the question arises as to what part of it is potentially or actually fit for human use. First, more than one commodity may be obtained from a single animal. The arctic fox is the source of pelts for sale, but its carcass can be fed to dogs. The beaver is also the source of a saleable pelt, but its meat may be eaten by humans. The caribou is primarily a source of food, but its skin is useful for bedding and sometimes for clothing. A proper evaluation of country produce, therefore, would have to take all these uses into account. It would also have to take into account the use of timber for housing, and the use of logs, driftwood or animal fats for heating.

At the present time, the use of country produce other than for food, or furs for sale, is limited. The main fur species go almost entirely for export, although wolf and wolverine pelts are highly valued for clothing, and most are used domestically - in the western Arctic at least. Some caribou skins are used for bedding and, south of the tree line, some moosehides are scraped and tanned for clothing. The transition from dogs to snowmobiles for haulage in winter in many areas has resulted in seals being sought primarily for their skins instead of for their meat 
and fat. Animal fats, formerly used for heat and light, are now surplus products, but new uses for them may be found in the future. Similarly, the use of wood for housing and for fuel is rare now that the provision by the government of low-rental housing for native people has led to an almost exclusive reliance on imported lumber for prefabricated construction, and fuel oil for home heating, but this may not be a permanent phenomenon.

Thus the use to which the animal harvest is put varies both with locality and time. Only sporadic observations and measurement of this use are available, and so caution is necessary in making generalizations from them. The value of country produce used for bedding, clothing, shelter and heat is now almost certainly less than ten per cent of the value of that used for food in most localities. This estimate is derived by the present author from his general knowledge of the western Arctic and Mackenzie Delta, and has not been brought into question in any suggestions made by either native people or other researchers.

These non-food values are not therefore given further consideration in this paper, though with the proviso that, even though they are of only small account in the traditional sector of the northern native economy, they are in some instances completely irreplaceable. No products of western technology have yet been able to equal the lightness, versatility and efficiency of caribou skins for bedding, wolverine fur for parka trim, or moose-hide for shoe soles and mitt palms. Furthermore, although there has been a more or less continuous decline in the use of domestic products for non-food use in recent years, it does not automatically follow that the trend will continue. Such an assumption in fact prejudices the evaluation of economic development alternatives, and so can become a self-fulfilling prophecy. This might be good politics, but hardly good science.

Even the measurement of the use of country produce for food alone is difficult. The actual number of animals used may be known, but not necessarily which parts and proportions. Cultural preferences vary with both locality and time, although certain broad generalizations can be made about the use of any particular animal. There may be a declining consumption of animal heads, certain internal organs, and fat, but again it cannot be assumed that the trend is a permanent one.

Using the data derived from a variety of sources, Foote (1965) and Usher (1971) have summarized total and component weights of most arctic species. Similar data are available for most northern woodland species. Such figures constitute a useful guide, but they cannot be applied with certainty in every instance. Geographical variations in the mean size of any species, differing selection for age and sex of animals according to various hunting traditions, and cultural variation in butchering techniques and food preferences, are all factors of uncertainty in calculating the volume of domestic meat consumption in the North.

It is certainly possible to estimate this volume, but much caution must be exercised in doing so, as well as in making use of the values derived. The data on which exact calculations can be based are not only unavailable at present, but will never become available. While individual investigators have been able to obtain remarkably detalled and exact information about the domestic economy in small villages or camps through active participation in community life over a period of months or years, it is entirely impracticable to obtain data at such a level 
of accuracy as a matter of course. All the results of these studies will provide are rough guidelines by which to assess the more general and continuous data series compiled by governments and trading companies; due to differences as between places and over time, there can be no simple set of guidelines which are universally applicable.

The compilation of comprehensive statistics on domestic food consumption on a regular basis for the purposes of territory-wide accounts (see Palmer 1973) or for monitoring purposes is, therefore, well-nigh impossible, and any study which purports to derive such data, or to rely on them, must be viewed with caution. Unrounded figures, such as are generally found in government statistics, tend to convey an impression of precision which is entirely unwarranted. On the basis of generally available data, one can be assured only that estimates derived from them, providing all considerations have been taken into account, are at least of the correct order of magnitude, and may even be within fifty per cent of the true figure. It is also safe to assume that government statistics consistently underestimate the true figures; but the degree to which they do so is of limited and variable predictability.

The foregoing remarks do not imply criticism of the government data collection systems which have been cited. While conceptual and mechanical improvements may indeed be desirable in these systems, they were not in fact set up to measure food production, and hence cannot be criticized for failing to do so. Rough estimates will have to suffice in the future, as they have in the past. One can only hope that the criteria for making such estimates will become widely enough known and well enough understood, and that they will be made explicit by those who attempt them.

\section{EVALUATION OF INCOME IN KIND}

The problem of evaluating income in kind has not received much serious attention in the context of hunting and trapping in the North. This may be due in part to the fact that most studies of the traditional economy of the North have been carried out by geographers and anthropologists without any special knowledge of economics. See, for example, the Area Economic Survey report series of the Department of Indian and Northern Affairs as well as Foote (1967) and Usher (1971).

At this point it is useful to examine the methods which have been developed in agricultural economics to measure income in kind, as received by farmers. In Canada a standard procedure exists for estimating such income in kind as a component of farm income (D.B.S. 1958). There are two sources of farm income in kind. The first "represents the value of that produce grown by farm operators and consumed in the farm house ... valued at its alternative market price, i.e. the price the farmer would have received had it been sold." (D.B.S. 1958 p. 16). Such produce includes food stuffs, wool and forest products - the domestically produced and consumed raw materials of subsistence (food, clothing, shelter and warmth) - valued at the opportunity cost of their consumption. The second source is imputed house rent, which is of no concern here, and in any event is not 
applicable to the northern domestic economy (Usher 1971 p. 113).

Attempts to evaluate country produce in non-agricultural subsistence economies have been few, and although in some respects the literature is consistent, most is without theoretical foundation. Dyke (1968), in a study of the household economy of outport Newfoundland, has used opportunity costs in some instances. In a study of Alaskan resources (F.F.C.D.P.A. 1968), values were assigned to country food on an unspecified basis. In a reference paper concerning the Northwest Territories of Canada (D.N.A. 1965), substitution costs were used, but no distinction was made between dog food and human food. Kelsall (1968), in his major study of the caribou, estimated the economic value of that animal on the basis of substitution costs, distinguishing between components used for human food and for dog food. Smith (1975) used local exchange values for the Mackenzie Delta, save in the case of caribou which was valued at the going price of reindeer.

The present author has used substitution costs in studies of the CoppermineHolman region (Usher 1965) and Banks Island (Usher 1971 p. 115). In the latter study, it was suggested that the value of reindeer meat sold commercially in the Mackenzie Delta should be used as the appropriate substitute for human food, and the retail value of cornmeal and tallow as the one for dog food, these being approximately $\$ 0.50$ and $\$ 0.25$ per pound $(0.45 \mathrm{~kg})$ of edible meat respectively at the time.

In several studies made more recently, attempts have been made to impute values to country food, mostly in connection with assessments of the socioeconomic impact of the proposed Mackenzie Valley gas pipeline. In one consultant's report on the impact of the pipeline, local exchange values were used, although the basis for arriving at them was not specified (C.A.G.P.L. 1974a).

This approach was criticized in a study of the Old Crow domestic fishery (DeLury et al. 1975 p. 47) in which the need to use substitution costs was emphasized. These were estimated to be $\$ 0.50$ per pound for dog food, and between $\$ 3.00$ and $\$ 4.00$ for human food. This, it was then suggested, implied "that work for a wage must be substituted for fishing. If this were the case, then for the sake of equality a man must have the same wage-power as fish power". On the basis of returns per unit of effort for fishing, the equivalent wage was estimated at about $\$ 7.00$ per hour. Since fishing is a seasonal activity, however, it is not clear that the totality of land-based activities of which fishing is but a part in fact yields this level of return. Nonetheless, the point is a valid one and has been given attention by the present writer (Usher $1971 \mathrm{pp} .117-8$ ).

In a government-sponsored study (Bissett $1973 \mathrm{pp}$. 30-31), separate values were assigned to each type of country food, apparently on a combined basis of substitution costs, nutritional value and local preference. Bissett acknowledged that his estimate of $\$ 0.75$ per pound of edible meat for moose and caribou was a conservative one, in view of rising prices for imported meats. In a subsequent study he used a value of $\$ 1.00$ to $\$ 1.25$ per pound for game meat, again on a substitution basis (Bissett 1974 p. 27). This increase from the value obtained during the previous study took "into account the current high costs of domestic meats as substitute foods", although the actual costs cited for domestic meats as of 1973 (Bissett 1974 p. 188) are much higher than this, and do not differ 
greatly from those listed in Table 2 of the present paper. The reasoning behind Bissett's assignment of substitution costs is thus somewhat obscure.

In a report by Gourdeau (1974) on the native use of resources, values of $\$ 0.70$ and $\$ 0.75$ per pound are imputed to fish, and $\$ 0.85$ to country meat, both presumably for human consumption, although that is not made explicit. These values are based on substitution costs, but it is not stated whether the designated substitutes are imported fish and red meat (in which case the figures are far too low), or local fish and game sold in the stores (in which case the data are unreliable, since such sales are at best sporadic, as explained below). One can only assume that the values quoted above are not misprints, since conversions to cents per kilogram are provided which bear no reasonable relation to the values per pound.

One recent study by the Canadian government ( $\mathrm{Lu} \mathrm{1972)}$ followed the same method as that used on Banks Island (Usher 1971), though the actual values used were slightly greater. In another government study, substitution costs were used, on the understanding that they constituted a welfare value (in the sense used in economics) rather than a market-equivalent value (Palmer $1973 \mathrm{pp}$. $49-51$ ); a value of $\$ 0.80$ per edible pound was imputed to all meats, though with an acknowledgement of its being an arbitrary value which could well be revised over time in accordance with changes in the consumer price index.

Of all the authors referred to, only two are economists ( $\mathrm{Lu}$ and Palmer), and only two attempt to give explicit theoretical justification for their method of evaluation (Palmer and Usher). All three are, however, in general agreement in adopting substitution costs as a basis for imputing value, as well as on their reasons for doing so. It is evident, however, from a perusal of works on the subject that two other methods have suggested themselves: one based on local exchange rates, and one on opportunity costs. Problems connected with them are now considered.

Local exchange rates, i.e., the prices at which trappers and hunters exchange commodities among themselves, are not always readily determinable. The transac-

TABLE 1. Values of country produce, Banks Island and Mackenzie Delta (dollars per pound).

\begin{tabular}{lccc}
\hline Item & $\begin{array}{c}\text { Local exchange } \\
\text { value (approx.) }\end{array}$ & $\begin{array}{c}\text { Commercial } \\
\text { landed value }\end{array}$ & $\begin{array}{c}\text { Substitution cost } \\
\text { (or retail price) }\end{array}$ \\
\hline Seal & 0.10 & n.a. & 0.221 \\
Caribou & n.a. & 0.302 & 0.502 \\
Ptarmigan & n.a. & $0.40^{3}$ & 0.553 \\
Fish & $0.10^{4}$ & 0.253 & 0.353 \\
\hline
\end{tabular}

n.a. Not applicable or not available.

1. Substitution cost based en equivalent cornmeal and tallow value.

2. Based on Mackenzie Delta reindeer herd operations. Price paid to producers is approxiand was derived from Hill (1967). Retail price applies to Mackenzie Delta outlets.

3. Based on price paid to producers and retail costs respectively, in the Mackenzie Delta (D. G. Smith, Department of Anthropology, Carleton University, Ottawa, personal communication, 23 April 1969).

4. Exchange value in Mackenzie Delta (D. G. Smith, personal communication, 23 April 1969). No value is available for Sachs Harbour.

Sources: as cited; field investigations. 
tions do not always occur, and even if they do, they may be in fulfillment of personal obligations, in which case there is no market transaction in the classical economic sense. Most food exchange takes place between relatives, with no money involved. Barter may occur, especially nowadays, with the availability of frequent air transport, which makes possible the exchange of commodities between settlements. The terms of such barter have not yet been studied, and so the prevailing equivalences - e.g., how many geese might be exchanged for a hind-quarter of moose - is not known. When cash exchange does occur, the evidence is conflicting, mainly because the price often depends on kinship or friendship between buyer and seller. In the last two years, the present writer has witnessed the selling of caribou privately for between twenty and fifty dollars. The low figures for local exchange values, where available (Table 1), are prima facie evidence that noneconomic considerations are operative in these transactions. It may therefore be concluded that local exchange rates are unsuitable for the determination of cash-equivalent values for country food according to either market or welfare criteria - the term "welfare" being again used in the economists' sense of personal and social well-being, or quality of life, rather than in the popular sense of a subsidy or indigence.

The problem of determining opportunity cost (i.e. alternative market price) in the North lies in the fact that country produce there is not harvested in the context of a cash or market economy. In the case of farm produce in the South, a small proportion is consumed domestically, while the bulk is sold commercially, and so market value is easily ascertained. In the North, opportunity cost can seldom be ascertained, since commercial traffic in local commodities is rare. Indeed, in some instances it is prohibited by law.

Substitution cost, on the other hand, is easier to determine; for, once a reasonable substitute is agreed upon, its price may be readily discovered at the local store. Actually, however, the determination of appropriate substitutes is more complex than might at first appear, but for the moment consideration can be given to the substitutes most commonly designated in treatises on the subject. Only food for human consumption will be considered, as in many areas dogs have lately become of only minor importance. There is general agreement that reasonablyequivalent domestic meats imported into a particular area may be regarded as substitutes for country food. As an exception, locally-produced reindeer meat has been so regarded, but as it is not now widely available, and the prospect of its becoming so in the foreseeable future is uncertain, it will be omitted from further consideration. Substitution cost is a welfare-equivalent measure, since it provides the answer to the question: "If a man did not, or could not, obtain country food, how much would it cost him to feed his family by buying the equivalent food at the store?"

In Table 1 are compared the prices obtained by these foregoing three methods in the western Arctic in 1967. The specific values are of course no longer valid, but the relative magnitudes are. (See, for example, the prices paid to producers, and retail country food prices, as quoted for the Inuvik region for 1973 in Bissett $1974 \mathrm{pp} .186-7$.) The data (Table 1) serve to support the thrust of the preceding discussion, and also reflect the dual nature of the northern economy. 
In terms of praticality, it would appear that substitution costs are the most readily ascertained, since the data are simply not available for some species by the use of other methods. Ideally, the choice of measurement should be a function of the objective at hand. Palmer (1973) correctly distinguishes between a marketequivalent and a welfare-equivalent value. If one seeks to measure the contribution of the native economy to the national economy, then a market-equivalent index, such as local exchange value or opportunity cost, would seem more appropriate. On the other hand, if one seeks to measure the welfare of the individual participating in the traditional sector - perhaps to compare it to that of the individual in the modern sector - then a welfare-equivalent index such as substitution cost is necessary.

In recent years, there appears to have been a greater interest in ascertaining the comparative welfare of native people than in measuring their direct contribution to the national product. Indeed, it is the announced policy of the Government of Canada that the needs of the native people are of the highest priority (Chrétien 1972); and from a perusal of recent reports by economists of the Department of Indian and Northern Affairs, it would seem that the latter are more concerned with welfare criteria than market ones, at least with regard to the place of native people in the economy of the North.

With respect to more specific issues of the potential impact of development, the choice depends on the perceived nature of the problem. If one can be sure that no conflict exists between the harvesting of modern non-renewable resources and that of traditional renewable resources, due either to environmental or socioeconomic factors, so that people will truly and invariably be free to participate in either sector, then market-equivalent measures are appropriate for establishing which activity makes a greater contribution to the total economy. If, on the other hand, there is a conflict, and the two activities prove to be mutually exclusive, then welfare-equivalent measures must be introduced, since the proposed development will obviously affect the welfare of the traditional users of the land.

There is good reason to believe that the latter case is the one more likely to occur. Certainly that is the view of many native people in the North who fear for their traditional land and life. They foresee the possibility that development will lead to an absolute reduction in the amount of country food available to them, so that they will be forced to live on food imported into the areas where they live. Many explicitly pose the question: "If the land is spoiled, how will we live? We cannot afford to buy food at the stores, especially with the high prices these days." In view of the current concerns of northern people and the debate over northern development, welfare-equivalent measures for the evaluation of country food are appropriate. Hence, for both practical and theoretical reasons, the use of substitution values is to be recommended for the purpose.

The first consistent use of substitution values in the analysis of the northern native economy occurred in the late nineteen sixties. Persons writing on the subject since then have frequently adopted the idea, but have failed to adjust the values for changing circumstances and prices. Whereas values of $\$ 0.50$ and $\$ 0.60$ per edible pound of meat may have had some basis in fact in the mid-sixties, the use of figures ranging from $\$ 0.60$ to $\$ 1.25$ in the mid-seventies is totally unrealistic. 
TABLE 2. Retail meat prices, western Arctic, 1974-75 (dollars per pound).

\begin{tabular}{lccc}
\hline Item & $\begin{array}{c}\text { Inuvik } \\
\text { April 1975 }\end{array}$ & $\begin{array}{c}\text { Aklavik } \\
\text { November 1974 }\end{array}$ & $\begin{array}{c}\text { Tuktoyaktuk } \\
\text { April 1975 }\end{array}$ \\
\hline T-bone steak & 3.09 & & \\
Rib steak & 2.39 & 2.95 & \\
Chuck steak & 1.73 & & \\
Hamburger & 1.45 & 2.50 & 1.81 \\
Pork chops & 1.79 & 3.45 & 1.45 \\
Chicken & 1.29 & & \\
Turkey & & 1.45 & \\
Beef heart & 0.98 & & \\
Halibut & 2.451 & & 2.06 \\
Haddock & 1.751 & & \\
Bacon & & 2.05 & 1.43 \\
Sausages & & 1.80 & \\
Wieners & & & \\
\hline
\end{tabular}

1. Packaged, frozen fillets.

2. Some weights estimated.

Source: field observations.

Only DeLury et al. (1975) have used realistic figures for substitution costs. In Table 2 are shown the prices of imported meats in the Mackenzie Delta during the winter of 1974-75. Realistic substitute values in the western Arctic at the present time would be more in the order of $\$ 2.50$ to $\$ 3.00$ per pound for red meat, $\$ 1.80$ for birds (due to waste on imported cuts, effective prices per edible pound are in many instances higher), and $\$ 2.00$ for fish. It will, incidentally, be evident from the same table that in the smaller, all-native communities, where people are most dependent on country food, the imported meat-substitutes are more expensive than in Inuvik where a transient white population predominates. Further, imported meats are not available in the smallest communities (such as Sachs Harbour on Banks Island, and Paulatuk on Darnley Bay to the east of the Mackenzie Delta). If they were made so, it may be assumed that freight charges would add substantially to their costs.

The designation of imported domestic meats as an appropriate substitute for country food must be examined further. For nutritional purposes, red meat can be replaced by cheap sources of protein such as beans or soymeal, by tinned meats, or by meats more similar in texture and taste, such as beef, pork and chicken. In view of the widespread distaste among native people for vegetables or tinned meats as main items of diet, there can be no question that the substitution of such items for country meat would imply a loss of welfare, regardless of price or quantity. To a lesser extent such is also the case with imported meats, as is discussed further below. In the current context, it does not seem reasonable to ascertain substitution costs on the basis of sources of protein radically different from those in common use.

One must also consider the nutritional value of the proposed substitute. In Table 3 are indicated the relative proportions of protein per unit of edible weight of various meats. Evidently, two pounds of country meats have the equivalent protein value of perhaps three pounds of imported red meats. If one assumes 
TABLE 3. Protein and fat content of wild and domestic meats (grams per 100 grams of edible portion, uncooked, wet).

\begin{tabular}{lrr||lcr}
\hline Item & Protein & Fat & Item & Protein & Fat \\
\hline Beefsteak & 16 & 25 & Caribou & 26 & 1.4 \\
Hamburger & 16 & 28 & Moose & 25 & 1.1 \\
Pork & 12 & 45 & Whale & 27 & 0.8 \\
Lamb & 16 & 28 & Ptarmigan & 27 & 1.8 \\
Chicken & 20 & 13 & Snow Goose & 24 & 6.1 \\
Wieners & 14 & 21 & Whitefish & 24 & 3.9 \\
& & & Trout & 23 & 2.1 \\
\hline
\end{tabular}

Note: The values indicated are averages of those supplied by Farmer and Neilson (1967), Farmer et al. (1971), Foote (1965), Ho et al. (1971) and Otto Schaefer, Charles Camsell Hospital, Edmonton,, Alberta (personal communication, 14 April 1975).

that the chief element of scarcity from which meat derives its value is in its protein content rather than its fat content, then on a protein-equivalent basis the value of caribou and moose is likely to approach $\$ 4.00$, or $\$ 4.50$ per pound, and birds $\$ 2.50$, while fish will remain at $\$ 2.00$. Protein content is only one, although perhaps the most significant, means of comparing the nutritional qualities of country food and imported substitutes. The example of protein content is just one means of highlighting the complexity of imputing appropriate values to country food.

It is necessary, however, to mention that in Table 3 the wild and domestic meats sampled may not be directly comparable. For example, it has been suggested in the literature of the subject that the protein content of lean beef is nearly as great as that of caribou or moose. In general, however, domestic meat has a higher fat content, both within the muscle tissue (i.e. it is marbled) and as a proportion of the total animal. Nutritional value of country food is, in part, dependent upon the condition of the animal and hence varies with the seasons.

Given the monetary values suggested, it becomes easier to see why native people are so concerned about the continued availability of country food. A family primarily dependent on the land which obtained, for example, a dozen caribou, 60 geese and 500 pounds $(230 \mathrm{~kg})$ of fish in a year, would have obtained the equivalent of $\$ 6,200$ worth of meat. Such a harvest would be a modest one in the western Arctic, although its components would vary from place to place, and there might be other products to consider, such as whale meat and muktuk. A man working for wages full time, and hunting at weekends and during holidays (a common practice in the western Arctic), might reasonably expect to get four caribou, 30 geese and 500 pounds of fish - together worth about $\$ 2,800$. Such are significant additions to the household economy. The total estimated volume of the meat harvest of the western Arctic (from Aklavik, Inuvik and Tuktoyaktuk in the Mackenzie Delta; and Paulatuk and Sachs Harbour referred to above) would, on a substitution basis, probably be worth over a million dollars annually.

The failure of previous investigators to appreciate the full value of country food has led to serious underestimation of the contribution of traditional hunting, fishing, etc. to the total regional economy (see, for example, C.A.G.P.L. 1974a,b), 
and hence to conclusions that some native communities at least are without a viable economic basis. To cite one example, it was concluded from this study that the annual per capita income of Tuktoyaktuk, including income in kind, was $\$ 775$ (C.A.G.P.L. 1974 b p. 443), which meant that every man, woman and child there somehow managed to live on about $\$ 2.00$ per day each. If this really included the cash equivalent of production in the domestic sector, then the people of Tuktoyaktuk are in imminent danger of starvation and freezing, for there is no possible way that people could feed, clothe and provide shelter for themselves on that amount of money. Yet, despite higher prices and greater needs in the North, a person from Tuktoyaktuk is, on average, manifestly better off than any resident of Toronto or Edmonton who actually lives on a similar amount. Such conclusions are in need of re-evaluation in view of the erroneous assumptions on which they are based.

A further consideration in evaluating income in kind is cost of production. In order to obtain income in kind, some investment must be made in time and equipment, and this should be subtracted from the value of the produce. The problem is that such data have rarely been obtained, and those that exist are either inapplicable to other regions because of different hunting practices and success ratios, or out of date, or both. The problem is similar to that of ascertaining food production with any precision. Comprehensive data will never be available on a regular basis, and existing studies can only be used as rough guides.

The determination of production costs is somewhat complex, but has been attempted in certain areas by such researchers as Foote (1967) and Usher (1971). The latter study - of the Banks Island hunters - is the only one in which production costs are compared directly with income in kind. It was found as a result of it that, in the mid-nineteen-sixties, caribou cost $\$ 0.12$ per pound to produce, and birds between $\$ 0.05$ and $\$ 0.27$ (Usher 1971 p. 116). The main varieties of meat consumed at Sachs Harbour cost about one quarter of their imputed value to produce, an estimate which does not include a valuation on labour, since it was concluded that there is no opportunity cost for such labour (Usher 1971 p. 118). It is uncertain whether this is still universally true for fulltime hunters and trappers, but it is certainly the case for those who hunt at weekends and during holidays.

It is not known to what extent the figures quoted above for Sachs Harbour applied to other parts of the North at that time. They are, of course, no longer valid, even for Sachs Harbour, although the ratios between them may have been maintained. The introduction of snowmobiles has certainly caused production costs to rise by more than the amount attributable to inflation alone (Usher 1972b), but the changing basis for imputing values to country produce has had a similar effect. If the cost of production is truly about one quarter of the value of country food, as so far computed, then the final imputed value (substitution cost less production cost) is still considerable. This may not be an unreasonable supposition, but one hesitates to generalize in the absence of more comprehensive data.

Recent data (1973-75) supplied by the Game Management Division of the Government of the Northwest Territories indicate that amounts expended on organized caribou hunts (i.e., charter costs, and sometimes grubstaking and ammu- 
nition costs) have been $\$ 0.15$ per pound of meat retrieved in the Aklavik region, between $\$ 0.22$ and $\$ 0.37$ in the Yellowknife region, and up to $\$ 0.51$ in the Spence Bay region (personal communication, Ben Hubert, December 1975). There is great variation in the factors influencing these figures, and so they provide no more than rough indications of cost. Further, they do not take account of all costs.

In conclusion, the use of substitution cost is the most appropriate method for imputing values to country food. Such values have been drastically underestimated in recent years. The imputed value of country food is no less subject to inflation than the cost of other commodities, and it may be assumed that it will continue to increase in the future. Actual values derived are necessarily imprecise, due to the absence of completely comparable substitutes.

\section{INTANGIBLES}

There are also a number of highly important, but non-quantifiable considerations to be borne in mind when cash values are being imputed by the methods indicated above. Such figures are useful only in that they provide some estimate of the monetary values of specific commodities to their producers in comparison to alternatives in the context of a modern market economy. Even this statement must be qualified, however; the monetary valuations do not, and cannot, indicate the value of hunting as a social or cultural activity or as a way of life, and they do not, and cannot, indicate the value to the native hunter of the environment which provides these resources.

There are certain qualifications which must be placed on even the limited use of the imputed values. First, as has been pointed out by Smith (1975 p. 106), not all forms of income are equal. Some may be thought of as more "powerful" than others, in the sense that they are more flexible and provide greater freedom of choice to the recipient. There are progressive limitations on what can be done with freely disposable cash, credit, welfare payments and income in kind. Income in kind is therefore the least "powerful" form of income, although obviously the more one has, the greater choice there is in the use to which other forms can be put.

The fact that income in kind may be the least "powerful" form of income does not imply that it is the least desirable. In a society where hunting prowess is held in high esteem, the rewards of the hunt are more than mere income. The obtaining of a high income in the form of country food obviously has important favourable connotations which the obtaining of large welfare payments, for example, does not.

Furthermore, imported meats may be the closest possible substitute for country food, but they are by no means perfect. Native people like country food better than store-bought food, and indeed many insist that a steady diet of imported foods would be abhorrent to them. This is no mere idiosyncrasy; country food not only tastes better, but it is also more satisfying and nutritious. There is no satisfactory substitute for it; hence the acceptance of anything which might be substituted for it entails an absolute loss of welfare of incalculable proportions for native people. 
Food preferences and habits are an important part of any cultural heritage, and are often very deep-rooted. In a society where hunting is a central tradition, foods have a richness of meaning which stems from their procurement, distribution and preparation, as well as their eating. There are special ways of eating native foods which are reflected in sitting arrangements, implements used, and the distribution of the food, and are important not only to the individual but to the family. The provision of frozen beef cuts to replace muktuk, caribou ribs, frozen fish and ptarmigan soup would destroy these arrangements just as surely as would the provision of beans and bread as substitutes. Country food has nutritional, social and cultural values which cannot be replaced by any substitute and cannot be measured by market criteria or evaluated in cash. In short, food is an integral part of a way of life. The importance of that way of life and the land which it sustains has been documented elsewhere - most recently and thoroughly by Freeman (1976) and Usher (1974). It is evident that the problem of imputing values to country produce in the North is not analogous to imputing values to home garden produce in the South.

Of all those who have attempted to evaluate country produce in the North, only J. Palmer (Department of Indian and Northern Affairs, Ottawa) has explicitly recognized the limitations just referred to. He correctly emphasizes that "the traditional sector and the market sector are two different economic systems" and that "to attempt to find 'the correct' price for these goods [country produce] is illusory" (Palmer 1973). He concludes that it is better to approximate these prices and appreciate their limitations than to ignore them entirely (personal communication to author, February 1975).

If hunting is more than the mere act of obtaining food, then it follows that an evaluation of country produce does not thereby amount to an evaluation of the activity of hunting. Much less so can it indicate the value of the lands from which the produce was obtained. It may be tempting to imagine that if only one could calculate the productive value of land used for traditional activity, then in the event of its being disturbed due to some major development project, it would be a straightforward matter to assess the proper compensation for the damage caused in terms of future production foregone - just as is done when areas of farming land are taken for highways, power pylons or oil wells. But the analogy is inappropriate, and the temptation must be resisted. The nature of the northern environment as a productive habitat is entirely different from that of southern farmlands or forests. It is frequently all of one piece, so that the elimination of any one part of it may reduce the value of the whole disproportionately.

There is no way one can evaluate a way of life, and there is no way to compensate for its loss. Modern industrial society commonly fails to distinguish between peoples' livelihoods and their ways of life, too often supposing that compensation for loss of the former is sufficient for the loss of the latter as well. The increasing resistance to this supposition by native people, as well as by some Canadians in the South, is good evidence that it is fallacious.

One final observation may be made. The idea of compensation by substitution is based on the assumption that the proposed substitute will be in reasonable and constant supply in perpetuity. In this author's view there is no assurance that 
Canadian society can guarantee itself the amount of red meat over the next few decades to which it has become accustomed in the past. If it cannot, then there is uncertainty about its ability to provide meat on a regular basis at realistic prices to parts of the country which are distant from producing areas and whose small populations and wealth endow them with little political power. Many native northerners are well aware of their good fortune in having plenty of meat at a time when they hear increasingly of undernourishment and starvation in other parts of the world. The North may well be the only place where a poor man's table is laden with meat as a matter of course. It would surely be the height of irresponsibility to impair the productivity of lands which can supply food only in the form of meat, at a time when the world may well be entering a period of food shortages - particularly meat shortages - of such proportions that we cannot now even imagine what they will mean to our daily lives and to our society.

\section{REFERENCES}

BISSETT, D. 1973. Impact of pipelines on traditional activities of hunter-trappers in the Territories, volume 5: regional impact of a northern gas pipeline. Canada, EnvironmentalSocial Committee, Northern Pipelines, Task Force on Northern Oil Development, Report no. 73-32.

. 1974. Resource harvests - hunters-trappers in the Mackenzie Valley. Canada, Environmental-Social Committee, Northern Pipelines, Task Force on Northern Oil Development, Report no. 74-42.

C.A.G.P.L. 1974a. The region. In: Social and Economic Impact of Proposed Arctic Gas Pipeline in Northern Canada, Vol. 2, Calgary, Alberta: Canadian Arctic Gas Pipeline Limited.

1974b. The traditional economy. In: Social and Economic Impact of Proposed Arctic Gas Pipeline in Northern Canada, Vol. 5, Calgary, Alberta: Canadian Arctic Gas Pipeline Limited.

CHRETIEN, J. 1972. A report on the Government's northern objectives, priorities and strategies for the '70s. Minutes of Proceedings and Evidence of the Standing Committee on Indian Affairs and Northern Development, 28 March 1972. Ottawa: House of Commons.

D.B.s. 1958. Handbook of Agricultural Statistics, Part II: Farm Income, 1926-57. Ottawa: Dominion Bureau of Statistics, Agricultural Divion.

DELURY, R. T., STEIGENBERGER, L. W. and ELSON, M. S. 1975. Aspects of the historical and present-day fisheries exploitation in the northern Yukon Territory. In: Steigenberger, L. W. et al., Northern Yukon Fisheries Studies, 1971-1974, Vol. 1; Canada, Environmental-Social Committee, Northern Pipelines, Task Force on Northern Oil Development.

D.N.A. 1965. The Northwest Territories Today: a Reference Paper for the Advisory Committee on the Development of Government in the Northwest Territories. Ottawa: Department of Northern Affairs and National Resources. p. 107.

DYKE, A. P. 1968. Subsistence production in the household economy of rural Newfoundland. In: Skolnik, M.L. (ed.), Viewpoints on Communities in Crisis, St. John's. Newfoundland: Memorial University, Institute of Social and Economic Research (Newfoundland Social and Economic Papers no. 1, p. 36.

FARMER, F. A. and NEILSON, H. R. 1967. The caloric value of meats and fish of northern Canada. Journal of the Canadian Dietetic Association, 28: 174-8.

FARMER, F. A., HO, M. L. and NEILSON, H. R. 1971. Analyses of meats eaten by humans or fed to dogs in the Arctic. Journal of the Canadian Dietetic Association, 32: 137-41.

F.F.C.D.P.A. (Federal Field Committee for Development Planning in Alaska) 1968. Alaska Natives and the Land. Washington, D.C.: Government Printing Office. p. 292.

FOoTE, D. C. 1965. Exploration and resource utilization in Northwestern Alaska before 1855. (Unpublished Ph.D thesis, McGill University, Montreal).

1967. The East Coast of Baffin Island, N.W.T.: An Area Economic Survey, 1966. Ottawa: Department of Indian Affairs and Northern Development, Industrial Division.

FREEMAN, M. M. R. 1976 (ed.) Inuit Land Use and Occupancy Report. Ottawa: Queen's Printer. (In press) 
GOURDEAU, E. 1974. The native use of resources in the context of the proposed Mackenzie gas pipeline. Environmental Impact Assessment of the Portion of the Mackenzie Gas Pipeline from Alaska to Alberta, Volume IV, Research Reports. Winnipeg: Environment Protection Board. pp. 293-307.

HILL, R. M. 1967. Mackenzie Reindeer Operations. Ottawa: Department of Indian Affairs and Northern Development (NCRC 67-1).

HO, M. L., FARMER, F. A. and NEILSON, H. R. 1971. Amino acid context of birds, fish and mammals from northern Canada. Journal of the Canadian Dietetic Association, 32: 198-203.

KELSALl, J. P. 1968. The Migratory Barren-ground Caribou of Canada. Ottawa: Department of Indian Affairs and Northern Development, Canadian Wildlife Service. p. 278.

IU, C. M. 1972. Estimation of Net Imputed Value of Edible Subsistence Production in Northwest Territories. Ottawa: Department of Indian Affairs and Northern Development, Economic Staff Group. pp. 2-5.

PALMER, J. 1973. Social Accounts for the North: Interim Paper no. 3: The Measurement of Incomes in the Yukon and Northwest Territories. Ottawa: Department of Indian Affairs and Northern Development, Economic Staff Group. pp. 46, 51.

SMITH, D. G. 1975. Natives and Outsiders: Pluralism in the Mackenzie River Delta, Northwest Territories. Ottawa: Department of Indian Affairs and Northern Development, Northern Research Division (MDRP-12).

USHER, P. J. 1965. Economic Basis and Resource Use of the Coppermine-Holman Region, N.W.T. Ottawa: Department of Northern Affairs and National Resources (NCRC 65-2). p. 224.

1971. The Bankslanders: Economy and Ecology of a Frontier Trapping Community, Volume 2: Economy and Ecology. Ottawa: Department of Indian Affairs and Northern Development (NSRG 71-2).

1972a. Hinterland culture shock. Canadian Dimension, 8(8): 26-31.

1972b. The use of snowmobiles for trapping on Banks Island. Arctic, 25 (3):

171-81.

1974. Eskimo land use and occupancy in the western Arctic. (Report on file at Inuit Tapirisat of Canada, Ottawa.)

1975a. The class system, metropolitan dominance of northern development. A paper presented to the Canadian Association of Geographers, Annual Meeting, Vancouver, 27 May 1975. Antipode (In press).

1975b. Historical Statistics Approximating Fur, Fish and Game Harvests Within Inuit Lands of the N.W.T. and Yukon, 1915-1974, with text; Volume 3: Renewable Resources Project. Ottawa: Inuit Tapirisat of Canada. 